\title{
EDUKASIA
}

\section{Scientific Attitudes in Islamic Education Learning: Relationship and the Role of Self-Efficacy and Social Support}

\author{
Eva Latipah \\ UIN Sunan Kalijaga, Yogyakarta, Indonesia \\ eva.latipah@uin-suka.ac.id \\ Hanif Cahyo Adi Kistoro \\ Universitas Ahmad Dahlan, Yogyakarta, Indonesia \\ hanif.kistoro@pai.uad.ac.id \\ Imaniyah Khairunnisa \\ SD Negeri 2 Panau, Palu, Indonesia \\ khairunnisashin@gmail.com
}

\begin{abstract}
Scientific attitude in Islamic education learning is a demand in the newest curriculum. Psychological factors that determine it is self-efficacy and social support. This study aims to examine correlation between self-efficacy and social support with students' scientific attitudes in Islamic education learning, partially and simultaneously. Subjects were 152 Madrasa Ibtidaiyah students. Instruments used are scientific attitude, self-efficacy, and social support scales. Data analysis techniques used regression analysis. Results showed that there's a significant positive correlation between self-efficacy and students' scientific attitude in Islamic education learning with $r=0.367$ and $p=0.000(p<0.05)$. There's a significant positive correlation between social support and scientific attitude in Islamic education learning with $r=0.381$ and $p=0.000(p<0.05)$. There's a positive and significant correlation between self-efficacy and social
\end{abstract}


support simultaneously with scientific attitude in Islamic education learning with $F=18.222$ and $p=0.000(p<0.05)$.

Keywords: self-efficacy, social support, scientific attitude, Islamic education learning.

\begin{abstract}
Abstrak
Sikap Ilmiah dalam Pembelajaran Pendidikan Islam: Hubungan dan Peran Efikasi Diri dan Dukungan Sosial. Pentingnya sikap ilmiah siswa dalam pembelajaran pendidikan agama Islam bukan hanya tuntutan kurikulum tertulis tetapi juga sebagai bagian dari kompetensi yang harus dicapai secara keseluruhan sebagai modal untuk menjadi manusia yang sadar lingkungan, sains, dan masyarakat. Faktor psikologis turut menentukan sikap ilmiah termasuk efikasi diri dan dukungan sosial. Penelitian ini bertujuan untuk menguji: a) korelasi antara self-efficacy dan sikap ilmiah siswa dalam pembelajaran pendidikan agama Islam, b) korelasi antara dukungan sosial dan sikap ilmiah siswa dalam pembelajaran pendidikan agama Islam, dan c) korelasi antara self-efficacy dan dukungan sosial secara bersama-sama dengan sikap ilmiah siswa dalam pembelajaran pendidikan agama Islam. Subjek penelitian adalah siswa Sekolah Dasar yang terdiri dari kelas ke empat, ke lima, dan keenam, dengan total 152 siswa. Instrumen yang digunakan dalam pengumpulan data adalah skala sikap ilmiah, skala self-efficacy, dan skala dukungan sosial. Teknik analisis data menggunakan analisis regresi. Hasil penelitian menunjukkan bahwa ada korelasi positif yang signifikan antara efikasi diri dan sikap ilmiah siswa dalam pembelajaran pendidikan agama Islam dengan $r=0,367$ dan $p=0,000(p<0,05)$. Ada korelasi positif yang signifikan antara dukungan sosial dan sikap ilmiah dalam pembelajaran pendidikan agama Islam dengan $r=0,381$ dan $p=0,000(p<0,05)$. Ada korelasi positif dan signifikan antara efikasi diri dan dukungan sosial secara bersama-sama dengan sikap ilmiah dalam pembelajaran pendidikan agama Islam dengan $\mathrm{F}=18,222$ dan $\mathrm{p}=0,000(\mathrm{p}<0,05)$.
\end{abstract}

Kata kunci: self-efficacy, dukungan sosial, sikap ilmiah, pembelajaran pendidikan agama Islam.

\title{
A. Introduction
}

The 2013 curriculum was implemented as an innovation to advance national education. The 2013 curriculum is designed to provide the broadest learning experience for students in developing the ability to behave, be knowledgeable and be skilled, and act (Kaimuddin, 2014). The 2013 curriculum also makes the scientific approach an approach in 
the learning process (Musfiqon dan Nurdyansyah, 2015). The scientific approach is a learning approach that is designed so that students actively construct concepts, laws or principles through the stages of observing, asking questions, collecting data, associating, and communicating (Sufairoh, 2016). Based on the description implicitly, it is implied that the 2013 curriculum does not only emphasize the intellectual aspect, but rather emphasizes the formation and development of attitudes. The realm of attitude in the 2013 curriculum is a realm that flanks the transformation of substance or teaching material so that students know about 'why'. Attitude competency is related to general values, namely spiritual values ( 1 st core competency) and social values (2nd core competency). Learning attitude is also associated with the characteristics of the subjects being taught (Prihadi, 2014). One of them is in PAI learning which is better known as scientific attitude. Scientific attitude is a condition in an individual accompanied by feelings and certain reasons to provide a response or response or behavior in order to obtain a fact based on science (Wicaksono, Anggit G., Widyaningrum, 2018). Wicaksono revealed scientific attitude as 'a state of mind that enables creative thinking about nature and natural phenomena, and engaging in valid scientific research on these phenomena'. Based on this definition scientific attitude is a state of mind that makes it possible to think about nature and natural phenomena and is involved in scientific research (Wicaksono, Anggit G., Widyaningrum, 2018). Hunaepi explained that scientific attitudes are one's views on ways of thinking in accordance with scientific methods, giving rise to a tendency to accept or reject ways of thinking that are appropriate to science, then manifested in their logic, emotions, or feelings as well as in their behavior (Hunaepi, 2016). Scientific attitude in learning including PAI learning is one of the important aspects that students must have. Carindan stated that PAI learning contained three things, namely process, product, and attitude. PAI learning ideally should not only study products, but also must learn aspects of the process and attitude so that students can truly understand PAI as a whole as is the nature and characteristics of PAI material (Wiryopranoto et al., 2017).

The importance of a student's scientific attitude in learning PAI is not only the demands of a written curriculum, but as part of the competency that must be achieved as a whole as capital to become an environmentally conscious human being, science, and society. Efforts to develop scientific attitudes in students continue to be made to form a generation that has a scientific attitude. But in reality the efforts to 
instill scientific attitudes have not been optimal, so that the scientific attitude of MI/SD students is still quite low. For example, in MI AlHikmah, Bandung Regency. The teacher tends to be quiet when none of the students ask or give an opinion. In other words, communication in learning PAI is still lacking. Teachers only focus on providing material without caring for students, student attention is not necessarily the direction. Coupled with PAI learning, which in its implementation is still minimal by experiencing (engaging) or experimenting, so PAI learning seems boring and students cannot engage their process skills and cannot develop scientific attitudes. Imbalanced learning between the process and the product causes students to not accept the concept or PAI material in full. This situation also affects student achievement and results in students' scientific attitudes being low. In addition to unbalanced learning factors, factors from within themselves and their environment can also be a cause of high or low student scientific attitudes. Students as individual beings have a variety of factors that can affect each of his actions. One of the influences from within is self-efficacy, which is a belief in its ability to regulate and issue the actions needed to produce the desired achievements successfully. Self-efficacy is a concept derived from social cognitive theory initiated by Albert Bandura (Flammer, 2015) and is a major factor that can influence human action.

Ruliyanti and Laksmiwati (2014) stated that self-efficacy can also affect student achievement. The theory that states that the onset and regulation of transactions with the environment is partly determined by self-efficacy assessments. Self-efficacy is self-confidence in the ability possessed to achieve the desired goals. High self-efficacy can make students more prepared, work harder, and have less negative emotional reactions when facing difficulties than those who doubt their abilities (Mahmudi \& Suroso, 2014). Self-efficacy also makes a difference in how people feel, think, and act (Yoenanto, 2010). Sinulingga (2014) also states that self-efficacy contributes to the strengths and weaknesses of student motivation. Based on some of the results of this study, it can be concluded that scientific attitudes can be possessed by students who have high self-efficacy.

Aside from being an individual creature, students are also social beings who are in the community and are always in contact with other individuals, in the family, the school environment and the community. The existence of students as social beings who are always in the midst of society, can provide a variety of factors that affect students, both from 
the cognitive, affective, and skill aspects. One external factor that can influence students' scientific attitudes is social support. Smet (Mahmudi \& Suroso, 2014) suggests that social support explains how a person's social relationships contribute to the benefits of individuals and function as social ties or ties. Social support is useful to reduce the impact of stresses suffered by individuals. With social support, individuals can feel that they are loved and cared for. Khaliq (Khaliq \& Alsa, 2015) states that social support students have can predict student learning achievement. Social support in this research emphasizes more on those from families and schools because the family is the first and foremost environment that gives a lot of influence to various aspects of child development, especially those related to the scientific attitude of children; While schools are the second place for children to study. Social support is sourced from the surrounding environment, as well as scientific attitudes that can be formed and developed from interactions. People who get high social support get a lot of emotional support, appreciation, instrumental, and informative, so he will have an optimistic view and confidence in his actions (Apollo \& Cahyadi, 2012).

Self-efficacy and social support are two factors that can influence a variety of individual actions. Self-efficacy as an internal factor and social support as an external factor. If both factors, namely self-efficacy and social support are owned by the individual, both of them together can help the individual in achieving the desired goal. This is consistent with the opinion expressed by Kirana which states that the self-efficacy and social support possessed by students has a correlation to academic achievement (Kirana \& Moordiningsih, 2010). Based on the background description above, the purpose of this study is to examine the effect of self-efficacy and social support on the scientific attitudes of SD / MI students in PAI learning.

\section{B. Discussion}

\section{Research Subject}

The subjects of this study consisted of 152 students in grades IV, V, and VI of the Madrasah Ibtidaiyah (Elementary School level) AlHikmah, Bandung Regency, West Java. More complete about the profile of the subject is shown in Table 1 . 
Table 1.

Description of Research Subject

\begin{tabular}{l|c|c|c}
\hline \multirow{2}{*}{\begin{tabular}{c} 
Program Class \\
\cline { 2 - 3 }
\end{tabular}} & \multicolumn{2}{|c|}{ Sex } & \multirow{2}{*}{ Age } \\
\cline { 2 - 3 } & Male & Female & \\
\hline Class IV & 25 & 28 & $9-10$ years \\
\hline Class V & 25 & 29 & $10-11$ years \\
\hline Class VI & 19 & 26 & $11-12$ years \\
\hline Number & 69 & 83 & \\
\hline
\end{tabular}

Based on Table 1, the number of class IV, V, and VI women is higher than that of men. This has to do with the level of academic achievement of students, where female students are better at academic achievement than men. In the case of opportunities to drop out at universities, however, women have less opportunity than men (Latipah, 2017). As shown in a number of studies (Santrock, 2011) that one of the causes of women is better in academic achievement and less in drop out opportunities because women are proven to have higher motivation to learn than men, and women are also more diverse in using strategies. learning strategies, which are adapted to the characteristics of the material. Motivation and learning strategies are two determining factors in educational success (academic achievement).

\section{Overall Data Description}

A description of the overall research data is shown in Table 2.

Table 2

Research Data Description $(\mathrm{N}=152)$

\begin{tabular}{l|c|c|c|c|c|c|c|c}
\hline \multirow{2}{*}{ ariabel } & \multicolumn{4}{c|}{ Empirik } & \multicolumn{4}{c}{ Hipotetik } \\
\cline { 2 - 10 } & Min & Max & Mean & SD & Min & Max & Mean & SD \\
\hline $\begin{array}{l}\text { Sikap Ilmiah } \\
\text { Pembelajaran PAI }\end{array}$ & 24 & 92 & 59,05 & 15,1811 & 19 & 95 & 57 & 12,6 \\
\hline Efikasi Diri & 27 & 75 & 57,71 & 10,353 & 15 & 75 & 45 & 10 \\
\hline Dukungan Sosial & 26 & 78 & 58,10 & 11,223 & 16 & 76 & 47 & 11 \\
\hline
\end{tabular}

The data description above is reinforced by the following categorization to determine the position of the subjects in the study. The results of categorization as shown in Table 3. 
Table 3

Subject categories are based on Self-Efficacy Variables

\begin{tabular}{ccc}
\hline Kategori & Frekuensi & Persentase \\
\hline Rendah $(>27-39)$ & 22 & 14,5 \\
\hline Sedang $(>39-51)$ & 101 & 66,4 \\
\hline Tinggi $(>51-63)$ & 29 & 19 \\
\hline Total & 152 & 100.00 \\
\hline
\end{tabular}

Referring to Table 3, there were 29 people (19\%) students who had high self-efficacy; While students who have moderate and low efficacy are 101 (66.4\%) and 22 people (14.5\%). Thus overall students as the subjects of this study have moderate self-efficacy. The results of categorizing social support variables are shown in Table 4.

Table 4

Subject Categories based on Social Support Variables

\begin{tabular}{lcc}
\hline \multicolumn{1}{c}{ Kategori } & Frekeunsi & Persentase \\
\hline Rendah $(>27-39)$ & 20 & 13 \\
\hline Sedang $(>39-51)$ & 110 & 70,3 \\
\hline Tinggi $(>51-63)$ & 24 & 16,4 \\
\hline Total & 152 & 100.00 \\
\hline
\end{tabular}

Referring to Table 4, there are 24 people (16.4\%) students who have high social support. While students who have moderate and low social support are $110(70.3 \%)$ and 20 people (13\%). Thus overall students as the subject of this study have moderate social support. The results of categorizing scientific attitude variables in PAI learning are shown in Table 5.

Table 5

Subject category based on Variable Scientific Attitudes in PAI Learning

\begin{tabular}{lcc}
\multicolumn{1}{c}{ Kategori } & Frekuensi & Persentase \\
\hline Rendah $(>27-39)$ & 18 & 11,8 \\
\hline Sedang $(>39-51)$ & 110 & 72,3 \\
\hline Tinggi $(>51-63)$ & 24 & 15,7 \\
\hline Total & 152 & 100.00 \\
\hline
\end{tabular}

Referring to Table 5, there are 24 people (15.7\%) students who have a high attitude in learning PAI. While students who have a religious attitude in learning PAI moderate and low are 110 (72.3\%) and 18 people (11.8\%). Thus overall students as the subject of this study have a faithful attitude in medium PAI learning. 


\section{Self-Efficacy and Scientific Attitude in PAI Learning}

Correlation test results between self-efficacy and scientific attitude in learning PAI obtained $r=0.367$ and $p=0.001(p<0.000)$. This means that there is a significant positive correlation between self-efficacy and scientific attitude in PAI learning; the higher students' confidence in their abilities, the higher their scientific attitude in PAI learning. This reinforces the findings that self-efficacy affects one's behavior (Klassen \& Tze, 2014) through four main psychological processes namely cognitive, motivational, affective, and selection (Flammer, 2015). Self-efficacy in cognitive processes takes various forms. Much human behavior, because it aims, is governed by previous thoughts which embody the goals that are valued. The setting of personal goals is influenced by self-assessment of ability. The stronger the self-efficacy, the higher the challenge people set goals for themselves and the stronger their commitment to them. Self-efficacy beliefs play a key role in regulating self-motivation. Most human motivation is cognitive. People motivate themselves and guide their actions anticipatively with the practice of forward thinking. They form beliefs about what they can do. They anticipate the possibility of prospective action outcomes. They set goals for themselves and plan actions designed to realize a valuable future.

Self-efficacy beliefs affect how much stress and depression they experience in a threatening or difficult situation, and their level of motivation (McLennan et al., 2017). The perceived effectiveness of self to control stressors plays a central role in arousal anxiety. People who believe they can exercise control over threats do not conjure up disturbing mindsets. But those who believe that they cannot manage the threat experience high anxiety. They dwell on their coping deficiency. They see many aspects of their environment fraught with danger. They increase the severity of possible threats and worry about rare things. Through such inefficient thinking, they suppress themselves and damage their level of function. The perceived self-efficacy coping regulates avoidance and anxiety. The stronger sense of self-efficacy of people who dare to take taxes and activities that threaten.

Some people are products of their environment. Therefore, belief in self-efficacy can shape the life taken by influencing the type of activity and environment chosen. The individual avoids activities and situations that they believe to exceed his coping abilities, but he easily undertakes challenging activities and chooses situations which he considers capable 
of being handled. With the choices he makes, individuals foster various competencies, interests, and social networks that determine the course of life. Whatever factors influence behavior, choices can greatly influence the direction of personal development. This is because social influences operating in the chosen environment continue to promote certain competencies, values, and interests long after the efficacy decision maker has had its inauguration effect (Wayan Suastra \& Ristiati, 2019).

The results of this study are also supported by Jenkins and Nelson (Preiss \& Sternberg, 2010) which state that scientific attitudes can be influenced by the level of self-efficacy owned by students. Student selfefficacy has been shown to correlate with a variety of specific subjects, related skills, and also have an effect on student performance; where scientific attitude as an affective domain is one of the determinants of student learning achievement in PAI learning (Slavin, 2006).

Students' confidence in their abilities that have a variety of effects can influence every action taken to achieve the desired goal. This can be achieved based on how much effort is made to complete learning tasks, efforts made to achieve learning achievement, and how long students can survive experiencing difficulties or failures in learning (Flammer, 2015). Confidence in the abilities possessed is not related to the amount of abilities and skills possessed, but to what students believe that they can do each learning task with their abilities. Self-efficacy is one's belief in his ability to change his tendencies in behavior (Animasahun et al., 2016). The efficacy that has been formed in each individual has a function and affects individual activities. The effect can be in the form of influence on cognitive processes, affection processes, motivational processes, and selective processes (Flammer, 2015). This agrees with Gist in (Slavin, 2006) which states that self-efficacy plays an important role in motivating individuals to complete challenging tasks.

Individuals having high self-efficacy perceive themselves as highly competent people. Conversely, individuals who have low self-efficacy consider themselves incompetent and assume failure is a result of their inability. If students have high self-efficacy, then it influences their mindset in learning, practicing, and developing their scientific abilities and attitudes in PAI learning. Students who have confidence in their abilities in the field of PAI have an impact on their PAI learning achievement. The student is able to perform a variety of study assignments given honestly, strong curiosity, and open-mindedness. 
Students who have confidence in their abilities, then these students are able to determine and do the learning they enjoy. Students feel more confident to complete each learning task given to him properly. When it is associated with learning science, students who have confidence are able to learn, demonstrate and apply one of the constituent elements of natural science, namely the scientific attitude. In addition to the beliefs held by students, the support received by students can also contribute to their attitudes and learning achievements. Students who receive this support always have the motivation to overcome the difficulties they face and have the motivation to always excel.

Students who have high self-efficacy in PAI learning feel confident in their ability to organize or arrange PAI materials. The same thing is done by students who have a scientific attitude in PAI learning, which is able to organize learning materials including PAI learning materials. Thus students who have the ability to organize as an indication of high selfefficacy also have a high scientific attitude. High self-efficacy students have the confidence to do a task. No matter how hard the task, students feel confident that he is able to do or complete the task. Especially in the teachings of religion conveyed that God (God) will not burden His servants beyond or beyond his abilities. If you get into trouble, students do not think that God has given tasks beyond their abilities, but rather it is a test or challenge from God so that he exertes all his efforts to do the task, because students on the other hand believe that God will not allow His servants to say as servants who believe if he is not tested. Of course also the teachings that reveal that in every difficulty there is ease makes students more confident that he can carry out PAI learning tasks well. The attitude of being convinced that it can perform tasks in PAI learning is highly demanded in a scientific attitude so that its targets or objectives are achieved.

High self-efficacy students also believe in their abilities that they can achieve a goal and produce something. As a result of his belief in being able to carry out his tasks in PAI learning, students believe that they can achieve their goals or objectives and can even produce something. Students with high scientific attitudes are not just scientific, but also produce something and even implement what he gets in real life everyday. 


\section{Social Support and Scientific Attitudes in PAI Learning}

Correlation test results between social support and scientific attitudes in PAI learning showed the value of $r=0.381$ and $p=0.001$. This means that social support is significantly positively related to students' scientific attitudes in PAI learning at MI Al-Hikmah, Bandung Regency. The contribution of social support to scientific attitude in PAI learning was $\mathrm{R}^{2}=0.145$, which means that social support contributed to the scientific attitude in PAI learning by $14.5 \%$. This positive influence means that the higher the social support of students, the higher the scientific attitude they have and vice versa, the lower the social support of students, the lower the scientific attitude they have.

The results of this study are supported by several studies which conclude that social support provides positive results for students (Mahmudi \& Suroso, 2014). Mattanah also stated that social support which is felt in general, allows one to be able to overcome difficulties and reduce negative effects in life (Loton \& Waters, 2017). Based on the results of these studies, it can be understood that students who have high social support will experience well-being in their lives, both in academic and non-academic life. Scientific attitudes on students can also be influenced by environmental factors, namely social support. As Baron and Byrne stated that social support is physical and psychological comfort provided by friends and family members. Social support can also be seen from the number of social contacts that occur or that individuals do in establishing relationships with resources in the environment (Ruliyanti \& Laksmiati, 2014).

The contribution of social support to individuals also affects their learning achievement. Feeling comfortable, valued, and acknowledgment from family as well as teachers and school friends gives a positive impact on the psychological condition of students which becomes the situation of students in receiving learning material. Providing support that is carried out on an ongoing basis can have a positive impact not only during the learning process, but can also be felt when students are dealing with learning evaluations (Prihadi, 2014). House also argues that with social support, one's psychological well-being is increased because of understanding, caring or giving rise to feelings of belonging, increasing self-esteem, and having positive feelings about oneself (Loton \& Waters, 2017). 
If students have strong support from family, teachers and classmates, then the student has a passion for achievement. Students who get support either verbal or non-verbal support, material or nonmaterial, obtained from family, teachers, and school friends are able to determine their attitude in acting is no exception to behave in accordance with scientific methods in carrying out PAI learning. As it is known that the scientific attitude itself is an attitude that can be formed from the environment. Achievement students, especially in PAI learning, are students who have knowledge about nature, students who have a high yearning desire, perseverance, discipline, critical thinking, respect for data and facts, love to work together and always care for the environment.

Social support is information or feedback from others that shows that someone is loved and cared for, valued, and respected, and involves in networks of communication and mutual obligations (Apollo \& Cahyadi, 2012). Social support in PAI learning takes the form of information or reciprocity from and between students to show that students pay attention to each other related to PAI learning. Attention has a positive psychological impact that makes them feel excited about learning PAI better. With high enthusiasm, all efforts and energy are mobilized to study PAI, including how to organize PAI learning materials, and how to better carry out PAI learning tasks.

Giving empathy, attention, affection, love, trust, acceptance, intimacy, encouragement, or care is a form of social support (Apollo \& Cahyadi, 2012). The point involves warmth and nurturing as a source of social support (Akker et al., 2006). Providing emotional support aims so that the recipient of support feels that he is valuable (Slavin, 2006). This support is also referred to as esteem support or appraisal support. Providing financial assistance, goods, or services (Heaney in McLennan et al., 2017) also called instrumental support, this form of support uses material to provide tangible (physical) and direct assistance to those in need. Giving advice, guidance, advice, or useful information for someone (Krause in LAM \& LAM, 2019). The type of support that gives a feeling of being accepted is part of a group and a sense of togetherness (also called belonging support). This is in the form of bringing friends to do social activities.

The contribution of social support to individuals also affects their learning achievement. Feeling comfortable, valued, and acknowledgment from family as well as teachers and school friends gives a positive 
impact on the psychological condition of students in receiving learning material. Provision of support carried out on an ongoing basis has a positive impact that is not only during the learning process, but can also be felt when students are dealing with learning evaluations. If students have strong support from family, teachers and school friends, then the student has a passion for achievement (Kirana \& Moordiningsih, 2010). Students who get support either verbal or non-verbal support, material or non-material, obtained from family, teachers, and school friends are able to determine their attitude in acting is no exception to behave in accordance with scientific methods in carrying out PAI learning. As it is known that the scientific attitude itself is an attitude that can be formed from the environment. Achievement students, especially in PAI learning, are students who have knowledge of religion, students who have a high yearning desire, perseverance, discipline, critical thinking, respect for data and facts, have the pleasure to cooperate and always care for the environment.

\section{Self-Efficacy and Social Support with Scientific Attitudes in PAI Learning}

The results of the multiple regression test prove that self-efficacy and social support have a positive influence on students' scientific attitudes in the learning of Islamic Education in Madrasah Ibtidaiyah $\mathrm{Al}-\mathrm{Hikmah}$. These results are evidenced by the $\mathrm{F}=18,222$ and $\mathrm{p}=0,000$ $(\mathrm{p}<0.05)$, which means that self-efficacy and social support together (simultaneous) have a positive and significant correlation on students' scientific attitudes in PAI learning at MI Al-Hikmah, Bandung Regency. In addition, for the results of the determination test it is known that selfefficacy and social support together contribute to the scientific attitude of students in learning at MI Al-Hikmah by $19.7 \%$, while the remaining $80.3 \%$ is influenced by other variables outside variable in this study. These joint (simultaneous) contributions appear to be greater than partial contributions.

The purpose of PAI in schools is to increase students' faith, understanding, appreciation, and experience of Islam, so that they become Muslim who believe and devote to Allah SWT and have good character in their private, social, national and state life (Kaimuddin, 2014). Based on this objective, there are four aspects of PAI's objectives, namely students 'belief in the teachings of Islam, understanding and reasoning and students' knowledge of the teachings of Islam, appreciation and 
inner experience felt by students in carrying out the teachings of Islam, as well as student experiences in faith, understanding, living, and practice the teachings of Islam in the life of the nation and state. To teach the four aspects of PAI learning, it takes a scientific attitude that is brave and polite in argumentation, being curious, caring about the environment, willing to cooperate, open, diligent, careful, creative and innovative, critical, disciplined, honest, objective, and having a high work ethic (Ministry of Education and Culture). In order for students to have a scientific attitude in PAI learning, students must have confidence in their ability to learn PAI and the support of various parties such as teachers, friends, parents, surrounding communities, and even stakeholders. Students' confidence in the ability to learn PAI is called self-efficacy, and support from various related elements is called social support. Self-efficacy and social support are psychological factors that also determine the success of PAI learning, including more specifically namely success in achieving students' understanding and reasoning in PAI learning.

The scientific attitude in PAI learning is demonstrated by having a curious attitude towards PAI materials, respect for data (respect for evidence), critical of data and reflecting it (critical-reflection), having an attitude of perseverance (perseverance), creative and there are inventions (creative and inventiveness), cooperation with others (cooperation with others), willingness to accept certainty (willingness to tolerate uncertainty).

Students who have confidence in their abilities, then these students are able to determine and do the learning they enjoy. Students feel more confident to complete each learning task given to him properly. When associated with PAI learning, students who have these beliefs are able to learn, demonstrate, and apply one of the constituent elements of religious knowledge, namely scientific attitude. In addition to the beliefs held by students, the support received by students can also contribute to their attitudes and learning achievements. Students who receive this support always have the motivation to overcome the difficulties they face and have the motivation to always excel. With social support someone gets information or feedback from others to show that he is loved, cared for, valued, respected, and involved in communication networks and mutual obligations (Slavin, 2006). Thus someone feels get help and has a special value because it has been helped. 
Social support provides the resources needed so that someone feels prosperous because when providing these aids people who provide assistance involve emotions, providing information, instrument assistance, and positive assessment of individuals in dealing with problems (Kirana \& Moordiningsih, 2010). Social support given by one student to other students in PAI learning can take various forms such as: assistance in the form of advice (appraisal support) related to the problem being faced, real assistance (tangiabel support) in the form of physical actions in completing assignments, support for feeling of competence or individual self-esteem or one's feelings as part of a group where the members have support related to one's self-esteem (self-esteem support), or showing feelings of being accepted as part of a group and a sense of belonging (belonging support) (Adicondro et al., 2012).

The results of interviews with a number of students as the subject of this study found that they felt the benefits of social support. If students have both factors, namely balanced belief and support. So both of these can have a positive influence on learning achievement, especially achievement in PAI learning. As Pophan said that the realm of scientific attitude determines one's success; This means that the realm of scientific attitude determines the success of a student to achieve mastery in the learning process, especially in PAI learning (Hunaepi, 2016). Some research on scientific attitudes also states that students who have high scientific attitudes will have fluency in thinking so that they are motivated to always excel and have a strong commitment to success (Suryani, 2016). Conversely, students who have a low scientific attitude tend to be less motivated in completing the tasks at hand.

A student who excels in PAI learning is a student who has a scientific attitude. Because studying PAI, besides learning concepts, principles, laws, theories, procedures, it also teaches scientific attitudes. In the aspect of scientific attitudes, students are taught to compare the facts found on the impact that may occur on learning outcomes. The scientific attitude aspect is also more oriented to taste or awareness. So it can be said that students who have a scientific attitude are students who have curiosity, discipline, honesty, are able to work together, think openly and enjoy doing PAI experiments. One way that can be done to improve students' scientific attitudes is to treat students as young scientists. This means that in PAI learning teachers should conduct demonstration experiments first, directly involve students in various learning activities, provide verbal and non-verbal guidance, and provide interesting and 
up-to-date information related to learning. The supports provided by the teacher are continuously and always carried out gradually, so slowly students can have an interest in PAI learning.

\section{Conclusions}

Based on the description above, it can be concluded that there is a positive and significant relationship between self-efficacy and scientific attitudes of students in PAI learning. The higher the self-efficacy, the higher the scientific attitude of students in PAI learning. High selfefficacy affects the mindset of students in learning, practicing, and developing their abilities and scientific attitudes in PAI learning. Students are able to do a variety of study assignments given honestly, diligently, discipline, and always have a curiosity. While students who have low selfefficacy, consider themselves incompetent and tend to avoid the given learning tasks.

Likewise there is a positive and significant relationship between social support and scientific attitude in learning Islamic education. The higher the social support, the higher the scientific attitude in PAI learning. Students who have high social support have positive things in life, can overcome the difficulties encountered and have lower anxiety. Students are also able to determine their attitude in acting according to scientific methods. Social support possessed by students also plays an important role in fostering student enthusiasm in achievement. Whereas students who have low social support tend to have higher anxiety and experience negative things in their lives.

The third finding from this study is that there is a positive and significant relationship between self-efficacy and social support together with scientific attitudes in PAI learning. Increased self-efficacy and social support together will be accompanied by an increase in scientific attitudes in learning Islamic education. The existence of confidence (selfefficacy) and social support students have, can make students able to find out, develop, and apply the scientific knowledge and attitudes they learn. Students who have high self-efficacy as well as get social support, are able to face any serious challenges during PAI learning.

Each research variable contributes (R2) different to scientific attitudes in the learning of PAI. Self-efficacy contributed to the scientific attitude in the learning of PAI by $13.5 \%$ while social support by $14.5 \%$. The self-efficacy and social support together contributed $19.7 \%$. Based 
on partial testing, social support contributes to the scientific attitude in learning PAI higher than self-efficacy. However, when tested together between self-efficacy and social support, it appears that its contribution is greater.

For the contribution of these two variables, both partially and simultaneously, it is recommended for students at the Secondary School level that in order for them to have a scientific attitude in PAI learning, they should increase social support and self-efficacy. Likewise for PAI teachers, it is necessary to provide support to their students so that they have high social support and self-efficacy through teaching, classroom management, and modeling (role models) for their students. 


\section{DAFTAR PUSTAKA}

Adicondro, N., Purnamasari, A., Psikologi, F., \& Dahlan, U. A. (2012). Efikasi Diri, Dukungan Sosial Keluarga Dan Self Regulated Learning Pada Siswa Kelas Viii. Humanitas, 8(1), 17-27. https:// doi.org/10.26555/humanitas.v8i1.448

Akker, J. Van den, Gravemeijer, K., McKenney, S., \& Nieveen, N. (2006). Introducing Educational Design Research. Educational Design Research, 2004, 1-163.

Animasahun, B., Madise-Wobo, A., \& Gbelee, O. (2016). Ventricular Septal Defects among Children in Lagos. British Journal of Medicine and Medical Research, 16(5), 1-10. https://doi. org/10.9734/bjmmr/2016/25984

Apollo, \& Cahyadi, A. (2012). Konflik peran ganda perempuan menikah yang bekerja ditinjau dari dukungan sosial keluarga. Program Studi Psikologi - Fakultas Psikologi Universitas Katolik Widya Mandala Madiun, 02(02), 255-271. http://download.portalgaruda.org/ article.php? article $=116765 \&$ val $=5324$

Flammer, A. (2015). Self-Efficacy. International Encyclopedia of the Social \& Behavioral Sciences: Second Edition, 4(1994), 504-508. https:// doi.org/10.1016/B978-0-08-097086-8.25033-2

Hunaepi. (2016). Kajian Literatur tentang Pentingnya Sikap Ilmiah. Prosiding Seminar Nasional Pusat Kajian Pendidikan Sains Dan Matematika Tahun 2016, November 2017, 548-550. https://doi. org/10.31227/osf.io/mpueg

Kaimuddin. (2014). Implementasi Pendidikan Karakter Dalam Kurikulum 2013. Dinamika Ikmu, 4(2), 47-64. https://doi. org/10.30738/sosio.v4i2.2982

Khaliq, I., \& Alsa, A. (2015). Belajar Berdasar Regulasi Diri dan Dukungan Sosial sebagai Prediktor Prestasi Belajar Matematika. Belajar Berdasar Regulasi Diri Dan Dukungan Sosial Sebagai Prediktor Prestasi Belajar Matematika, 1(2), 74-81. https://doi. org/10.22146/gamajop.7345

Kirana, A., \& Moordiningsih. (2010). Studi korelasi efikasi diri dan dukungan sosial dengan prestasi akademik : telaah pada siswa 
perguruan tinggi. Indigenous, Jurnal Ilmiah Berkala Psikologi, 12, 47-54.

Klassen, R. M., \& Tze, V. M. C. (2014). Teachers' self-efficacy, personality, and teaching effectiveness: A meta-analysis. Educational Research Review, 12, 59-76. https://doi.org/10.1016/j. edurev.2014.06.001

LAM, B., \& LAM, B. (2019). Social Support Giving and Teacher Development. In Social Support, Well-being, and Teacher Development. https://doi.org/10.1007/978-981-13-3577-8_6

Latipah, E. (2017). Psikologi Dasar bagi Guru. In Metode Etnografi, Edisi II. PT Remaja Rosdakarya, Bandung.

Loton, D. J., \& Waters, L. E. (2017). The mediating effect of self-efficacy in the connections between strength-based parenting, happiness and psychological distress in teens. Frontiers in Psychology, 8(OCT), 1-13. https://doi.org/10.3389/fpsyg.2017.01707

Mahmudi, M. H., \& Suroso, S. (2014). Efikasi Diri, Dukungan Sosial dan Penyesuaian Diri Dalam Belajar. Persona:Jurnal Psikologi Indonesia, 3(02), 183-194. https://doi.org/10.30996/persona. v3i02.382

McLennan, B., McIlveen, P., \& Perera, H. N. (2017). Pre-service teachers' self-efficacy mediates the relationship between career adaptability and career optimism. Teaching and Teacher Education, 63, 176185. https://doi.org/10.1016/j.tate.2016.12.022

Musfiqon dan Nurdyansyah. (2015). Pendekatan Pembelajaran Saintifik.

Preiss, D. D., \& Sternberg, R. J. (2010). innovations in Educational Psychology perspectives on learning,tecahing and human development. Spinger Publishing Company.

Prihadi, B. (2014). Penerapan langkah-Langkah Pembelajaran dengan Pendekatan Saintifik dalam Kurikulum 2013. 1-8. http:// staffnew.uny.ac.id/upload/131662618/pengabdian/penerapanpendekatan-saintifik.pdf

Ruliyanti, B. D., \& Laksmiati, H. (2014). Hubungan antara Self Efficacy dan Self Regulated Learning dengan Prestasi Akademik Matematika Siswa SMAN 2 Bangkalan. Character, 3(2), 1-7.

Santrock, J. W. (2011). Educational Psychology Fifth Edition. 
Slavin, R. E. (2006). EDUCATIONAL PSYCHOLOGY Theory and Practice Eight Edition. In Pearson (Vol. 53, Issue 9). https://doi. org/10.1017/CBO9781107415324.004

Sufairoh. (2016). Pendekatan Saintifik \& Model Pembelajaran K-13. Bahastra, 37(1), 89. https://doi.org/10.26555/bahastra. v37i1.5641

Suryani, I. (2016). Pengembangan Instrumen Penilaian Sikap Ilmiah Pada Pembelajaran Dengan Model Latihan Penelitian Di Sekolah Dasar. PEDADIDAKTIKA: Jurnal Ilmiah Pendidikan Guru Sekolah Dasar, 3(2), 217-227.

Wayan Suastra, I., \& Ristiati, N. P. (2019). Developing Critical Thinking, Scientific Attitude, and Self-efficacy in Students through Project Based Learning and Authentic Assessment in Science Teaching at Junior High School. Journal of Physics: Conference Series, 1233(1), 0-9. https://doi.org/10.1088/1742-6596/1233/1/012087

Wicaksono, Anggit G., Widyaningrum, R. (2018). EFEKTIVITAS PENGGUNAAN KOMIK BERBASIS SIKAP ILMIAH TERHADAP SIKAP PEDULI LINGKUNGAN MAHASISWA UNIVERSITAS SLAMET RIYADI. 4(2), 72-78.

Wiryopranoto, S., Herlina, N., Marhandono, D., \& Tangkilisan, Y. B. (2017). Ki Hajar Dewantara Pemikiran dan Perjuangannya.

Yoenanto, N. H. (2010). Hubungan antara Self Regulated Learning dengan Self Efficacy pada siswa akselerasi sekolah menengah pertama di Jawa Timur. INSAN, 12(Agustus), 1-10. https://doi. org/10.1109/COMPSAC.2011.4 